\title{
KONSEP BERPIKIR POSITIF (HUSNUZHON) DALAM MENINGKATKAN KEMAMPUAN SELF HEALING
}

Hardiyanti Rahmah

rahmah.anwar@gmail.com

\begin{abstract}
Abstrak
Self Healing merupakan salah satu cara penyembuhan diri dengan cara nonfarmakologi, yaitu mengeluarkan perasaan dan emosi dengan dilakukan secara mandiri oleh diri individu sendiri. Pada konsep husnuzhon atau kemampuan berpikir positif maka proses self healing dapat meningkat, saat individu mampu meningkatkan kemampuannya dalam berpikir positif. Adapun tujuan penelitian ini berfokus membahas konsep-konsep dalam berpikir positif untuk meningkatkan kemampuan self-healing. Adapun metode penelitian ini menggunakan studi literatur atau studi pustaka. Hasil pembahasan dalam studi literatur ini dianalisis dari berbagai jurnal penelitian dan buku teks yang berkaitan dengan variabel berpikir positif (husnuzhon) dan self healing yang menunjukkan adanya peningkatan kemampuan penyembuhan diri sendiri ketika individu mampu berpikir positif.
\end{abstract}

Kata kunci : Berpikir Positif, Husnuzhon, Self Healing

\section{PENDAHULUAN}

Pada beberapa keadaan, banyak sekali penyakit-penyakit baik fisik ataupun psikologis memiliki perkembangan atau tingkat kesembuhan yang lebih lambat, hal ini dikarenakan konsep berpikir individu cenderung merasa putus asa, marah dan tidak berdaya. Sebagaimana penelitian tentang pasien dengan gagal ginjal yang mengalami tingkat kesembuhan yang lambat walaupun sudah mendapatkan pengobatan medis. Maka dari itu peneliti tersebut melakukan pendekatan Islamic Self Healing untuk meningkatkan kualitas hidup para pasien dan pada hasil penelitian menunjukkan bahwa adanya peningkatan kualitas hidup para pasien 
Hardiyanti Rahmah : Konsep Berpikir Positif (Husnuzhon) Dalam Meningkatkan Kemampuan Self Healing

gagal ginjal tersebut. ${ }^{1}$

Pada kondisi tertentu, individu akan cenderung sulit menerima keadaan yang menimpanya, baik yang berkaitan dengan adanya sakit fisik ataupun adanya permasalahan psikologis yang berat. Bantuan tenaga profesional sangat berperan penting sebagai upaya kesembuhan atau peningkatan kembali kemampuan individu tersebut yang sudah menurun. Namun, selain mendapatkan bantuan dari tenaga ahli di bidangnya, sangat penting juga bagi orang-orang yang dalam proses penyembuhan tersebut belajar melakukan self healing, dimana mereka memaksimalkan proses penyembuhannya secara mandiri dengan melakukan beberapa metode dari self healing.

Dalam metode self healing sendiri terdiri dari berbagai macam cara, salah satunya menggunakan pendekatan agama, seperti melakukan self healing dengan metode doa, dimana pada penelitian ini menunjukkan bahwa terapi self healing metode doa mampu menurunkan tingkat kecemasan pada lansia di Panti Jompo. ${ }^{2}$

Berdasarkan beberapa konsep pendekatan metode self healing tersebut, maka pada penelitian ini pembahasan self healing yang akan dikaji oleh peneliti melalui studi literatur adalah bagaimana konsep dari berpikir positif (husnuzhon) dapat meningkatkan kemampuan self healing seseorang.

Hal tersebut diarenakan dari beberapa penelitian terdahulu yang sudah dilakukan menunjukkan bahwa terapi self healing ini dapat dilakukan dengan menggunakan pendekatan spiritual atau agama, selain juga pada aspek kesehatan dan sains. ${ }^{3}$

Pada konsep berpikir positif (husnuzhon) yang juga merupakan salah satu pendekatan agama, dimana dimensi kemampuan berpikir positif merupakan aspek religiusitas dari dimensi ibadah, maka dengan mengembangkan kemampuan

\footnotetext{
${ }^{1}$ Cita, E. E., Wulandari, T., \& Istanti, Y. P.. Terapi islamic self healing terhadap quality of life pada klien gagal ginjal kronis dengan terapi hemodialisa. (Mubammadiyah Jurnal of Nursing, 2016), h.43.

2 Dominggo, J. A., Parjo \& Herman. Pengaruh terapi self healing metode doa terhadap skor kecemasan pada lansia di panti jompo graha kasih bapa kecamatan sungai raya kabupaten kubu raya. (Jurnal Proners, 2019). h.2.

${ }^{3}$ Salisah. Komunikasi spiritual sebagai kajian interdisipliner antara aspek keagamaan, ilmu kesehatan dan sains: studi tentang self-healing. (Proceedings AICIS XII, 2012). h.1115.
}

Al Qalam: Jurnal Ilmiah Keagamaan dan Kemasyarakatan Vol. 15, No. 2

Juli-Desember 2021 
Hardiyanti Rahmah : Konsep Berpikir Positif (Husnuzhon) Dalam Meningkatkan Kemampuan Self Healing

berpikir positif tersebut diharapkan membantu individu dalam meningkatkan kemampuan self healing. ${ }^{4}$

\section{Self Healing}

Self healing terdiri dari dua kata Self dan Healing, Self berarti diri yang menunjuk kepada diri sendiri dan Healing berarti pengobatan atau sesuatu yang ada kaitannya dengan pengobatan. Pada proses pengobatan tersebut terdapat berbagai macam cara sebagai upaya proses penyembuhan, seperti melakukan pengobatan dengan datang ke dokter, psikiater, psikolog atau tenaga ahli lainnya sesuai penyakit atau masalah yang dialami.

Self-healing merupakan metode penyembuhan penyakit bukan dengan obat, melainkan menyembuhkan dan mengeluarkan perasaan dan emosi yang terpendam di dalam tubuh. Jika diartikan menurut bahasa, maka Self-healing berarti penyembuhan sendiri. Pada terapi Self-healing, salah satunya berprinsip bahwa sebenarnya tubuh manusia merupakan sesuatu yang mampu memperbaiki dan menyembuhkan diri melalui cara-cara tertentu secara alamiah. ${ }^{5}$

Self healing adalah fase yang diterapkan pada proses pemulihan atau penyembuhan dari berbagai penyakit fisik ataupun masalah psikologis seperti kondisi trauma, depresi dan gangguan psikologis lainnya. Pada terapi Self healing ini prosedur penyembuhan diri sendiri memiliki tujuan untuk mengurangi berbagai macam perasaan negatif dari masalah mental yang dimiliki. Proses self healing dapat membantu dalam penyelesaian masalah psikologis seperti unfinished business yang dialami dengan menggunakan berbagai teknik seperti melakukan meditasi, berolahraga, meningkatkan ibadah serta kegiatan lain yang bertujuan untuk relaksasi dan refleksi diri. ${ }^{6}$

\footnotetext{
${ }^{4}$ Siddik, I. N., \& Uyun, Q. Khusnudzon dan psychological well being pada orang dengan hiv/aids. (Psikis-Jurnal Psikologi Islami, 2017). h.86.

${ }^{5}$ Salisah. Komunikasi spiritual sebagai kajian interdisipliner antara aspek keagamaan, ilmu kesehatan dan sains: studi tentang self-healing. h.1118.

6 Islami, L. A. Self Healing dalam mengatasi Post Power Syndrome. (Skripsi. IAIN Sultan Maulana Hasanuddin Banten: Bimbingan dan Konseling Islam. 2016). h.30.
}

Al Qalam: Jurnal Ilmiah Keagamaan dan Kemasyarakatan Vol. 15, No. 2 Juli-Desember 2021 
Hardiyanti Rahmah : Konsep Berpikir Positif (Husnuzhon) Dalam Meningkatkan Kemampuan Self Healing

\section{Berpikir Positif (Husnuzhon)}

Berpikir positif atau berprasangka baik atau dalam agama islam dikenal dengan istilah husnuzhon merupakan kemampuan berprasangka baik kepada Allah Subhana Wa Ta'ala (SWT). Dasar dari prinsip husnuzhon adalah hadits nabi yang berbunyi: Dari Abu Hurairah radhiyallahu 'anhu, ia berkata bahwa Nabi shallallahu 'alaihi wa sallam bersabda, "Allah Ta'ala berfirman: Aku sesuai persangkaan hamba-Ku. Aku bersamanya ketika ia mengingat-Ku. Jika ia mengingat-Ku saat bersendirian, Aku akan mengingatnya dalam diri-Ku. Jika ia mengingat-Ku di suatu kumpulan, Aku akan mengingatnya di kumpulan yang lebih baik daripada pada itu (kumpulan malaikat)." (Muttafaqun 'alaih) (HR. Bukhari, no. 6970 dan Muslim, no. 2675).

Pada penjelasan hadits tersebut menjelaskan bahwa Allah SWT akan menyesuaikan persangkaanNya sebagaimana yang disangkakan oleh hambaNya. Maka dengan seringnya seseorang berpikir positif akan terwujud juga hal positif tersebut dalam kehidupannya.

Adapun dalam variabel religiusitas, kemampuan berpikir positif merupakan bagian atau bentuk dari dimensi ibadah dimana individu diharapkan dapat mengambil anggapan atau pikiran dengan baik ataupun positif terhadap sesuatu yang terjadi atau yang dia alami dalam hidup. Harapannya adalah dengan membiasakan kemampuan berpikir positif, maka individu tersebut dapat menumbuhkan rasa optimis dan percaya diri dalam melewati setiap proses pengalaman hidup.

Dalam fungsi religiusitas sendiri secara keseluruhan terdiri dari lima aspek yang terdiri dari, keyakinan, peribadatan atau ibadah, penghayatan, pengetahuan dan yang terakhir pengalaman. ${ }^{7}$ Pada konsep peribadatan atau ibadah yang ada kemampuan untuk berpikir positifnya tersebut menunjukkan bahwa konsep berpikir positif adalah bagian dari proses beragama terutama dalam hal ibadah.

Berpikir positif merupakan bentuk dari proses kognitif yang dapat mengubah cara pandang individu terhadap dirinya dan lingkungannya. Tingkat kepuasan

\footnotetext{
${ }^{7}$ Holdcroft, B. What is religiosity?(Journal of Inquiry and Practice, 2006). h.90.
} 
Hardiyanti Rahmah : Konsep Berpikir Positif (Husnuzhon) Dalam Meningkatkan Kemampuan Self Healing

individu terhadap kehidupan akan dipengaruhi oleh bagaimana cara mereka berpikir dan memandang kehidupan. ${ }^{8}$

\section{METODE}

Pada penelitian ini menggunakan penelitian kualitatif yang berbasis pada studi literatur. Hasil penelitian pada penelitian ini didapatkan dengan menggali atau menganalisis berbagai teori melalui beberapa literatur penelitian seperti jurnal penelitian. ${ }^{9}$ Penggunaan metode penelitian ini sebagai pendukung dari tujuan penulisan, yaitu untuk membandingkan dan mengkaji beberapa paradigma keilmuan yang berbeda dan variatif.

Adapun pada penelitian ini peneliti mengkaji beberapa hasil penelitianpenelitian terdahulu yang berkaitan dengan beberapa variabel yang sudah ditentukan oleh peneliti, melalui media jurnal penelitian, skripsi dan buku yang memiliki tema saling berkaitan.

\section{HASIL DAN DISKUSI}

Pada setiap individu memiliki kemampuan dalam melakukan self healing, namun pada proses self healing tersebut ada yang cepat dalam mendukung atau meningkatkan kesembuhan ada juga yang masih cukup lambat dan perlahan. Pada beberapa hasil penelitian menunjukkan bahwa self healing dengan pendekatan spritualitas seperti Berdoa mampu menurunkan kecemasan pada lansia. ${ }^{10}$

Pada pendekatan tersebut yaitu melalui metode doa-doa yang baik, menunjukkan bahwa individu tersebut secara tidak langsung akan memunculkan prasangka baik atau pikiran positif terlebih dahulu dengan adanya harapan bahwa doa yang mereka sampaikan di setiap kesempatan bisa membantu kesembuhan mereka.

\footnotetext{
8 Rusydi, A. Husn al-zhann: konsep berpikir positif dalam perspektif psikologi islam dan manfaatnya bagi kesehatan mental. (Proyeksi, 2012). h.3

${ }^{9}$ Moleong, L. J. Metodologi Penelitian Kualitatif. (ROSDA : Bandung. 2014), h.9.

${ }^{10}$ Dominggo, J. A., Parjo \& Herman. Pengaruh terapi self healing metode doa terhadap skor kecemasan pada lansia di panti jompo graha kasih bapa kecamatan sungai raya kabupaten kubu raya. h.4.
}

Al Qalam: Jurnal Ilmiah Keagamaan dan Kemasyarakatan Vol. 15, No. 2 Juli-Desember 2021 
Hardiyanti Rahmah : Konsep Berpikir Positif (Husnuzhon) Dalam Meningkatkan Kemampuan Self Healing

Pada konsep berpikir positif (husnuzhon), secara tidak langsung kita sudah mempersepsi kognitif untuk terus memikirkan segala hal baik, yang membuat diri kita secara sadar akan mendukung segala hal baik tersebut untuk terjadi, karena adanya harapan yang besar mulai tumbuh untuk kesembuhan atas penyakit yang sedang dialami.

Salah satu penelitian yang membahas tentang bagaimana Husnuzhon dapat menurunkan tingkat kecemasan mahasiswa menunjukkan bahwa, dalam proses Husnuzhon ini dapat membantu meningkatkan kemampuan dalam menurunkan permasalahan pada fungsi psikologis seperti kecemasan tersebut. Pada penelitian ini menunjukkan bahwa dengan adanya kemampuan individu dalam berpikir positif maka akan tumbuh perasaan-perasaan baik dari dalam diri individu tersebut, seperti rasa percaya diri, berkurangnya kekhawatiran ataupun ketakutan dan munculnya harapan yang besar, yaitu merasa akan selalu mendapat pertolongan dan perlindungan oleh Tuhan jika mereka sedang mendapat masalah. ${ }^{11}$

Pada dasarnya konsep dari Husnuzhon dapat membantu individu untuk menguatkan dan melatih kemampuan kognitif saat menyikapi segala hal yang dialami dalam kehidupan dengan lebih baik dan lebih positif. Hal ini dilakukan dengan mengutamakan persepsi atau anggapan yang lebih baik daripada harus memikirkan hal-hal buruk dan negatif yang belum terjadi.

Dalam konsep self healing sendiri dimana kemampuan penyembuhan diri dilakukan secara mandiri, maka proses kognitif untuk memiliki kemampuan dalam berpikir positif memiliki peran yang besar. Hal ini didasarkan dari beberapa pendekatan dalam self healing, seperti yang dilakukan oleh salah satu penelitian yang menggunakan Mind Healing Technique (MHT), dengan melakukan relaksasi pikiran dan pernafasan, berdoa, serta memberi afirmasi positif kepada diri sendiri. Pada penelitian ini diketahui bahwa dalam melakukan beberapa pendekatan pada proses self healing tersebut menunjukkan kepada hal yang positif, dimana

\footnotetext{
${ }^{11}$ Fairuzzahra, D. A., Aryandari, D.. \& Purwadi, M. Hubungan antara husnudzon dan kecemasan pada mahasiswa. (Jurnal Psikologi Islam, 2018). h.70.
}

Al Qalam: Jurnal Ilmiah Keagamaan dan Kemasyarakatan Vol. 15, No. 2

Juli-Desember 2021 
Hardiyanti Rahmah : Konsep Berpikir Positif (Husnuzhon) Dalam Meningkatkan Kemampuan Self Healing

penelitian ini juga mengkaji nilai-nilai sufistik yang muncul yaitu nilai sabar, nilai pasrah, nilai tawakkal, konsep takhalli dan tahalli, nilai ridha dan nilai syukur. ${ }^{12}$

Berdasarkan beberapa hasil penelitian tersebut menunjukkan bahwa untuk membantu proses self healing maka kemampuan kognitif untuk merespon proses berpikir dengan baik dan positif sangat diperlukan, karena pikiran yang positif tersebut akan mampu membuat individu memunculkan sikap optimis dan mengurangi perasaan khawatir serta rasa takut terhadap hal-hal negatif yang sebenarnya belum terjadi.

Selain itu, konsep husnuzhon tersebut juga akan mendekatkan hubungan manusia dengan Tuhannya, dimana dengan munculnya pikiran-pikiran positif tersebut akan menumbuhkan rasa syukur pada manusia terhadap kehidupannya dan kemampuan bersabar dalam melewati proses penyembuhan baik dari penyakit fisik ataupun permasalahan psikologis yang mereka alami. Hal ini dikuatkan oleh penelitian yang menunjukkan bahwa orang dengan HIV/AIDS saat mereka mampu menumbuhkan pikiran yang positif dan berprasangka baik kepada Allah SWT maka kesejahteraan psikologis yang mereka miliki juga semakin tinggi. Serta mereka mampu menjalani hidup dengan lebih sejahtera walaupun memiliki penyakit tersebut, karena mereka merasa ada Allah SWT yang akan selalu menjaga dan melindungi mereka. ${ }^{13}$

Pada prosesnya, husnuzhon merupakan proses kognitif dimana proses berpikir akan menjadi awal dari munculnya sebuah perilaku berdasarkan persepsi yang dibuat. Saat individu tersebut mampu untuk menerapkan pikiran positif dalam menyikapi kondisi yang menimpa dirinya, maka sikap yang muncul juga akan menjadi positif. Sebagaimana pikiran negatif yang membuat munculnya perilaku negatif juga. Pada kondisi inilah konsep Husnuzhon tersebut dapat membantu individu dalam meningkatkan kemampuan self healing. Dimana kemampuan berpikir positif ini dapat memberi harapan baik pada individu tentang apa yang akan

\footnotetext{
12 Rahmawati, A. P., Setiawan, C. \& Naan. Nilai sufistik dalam prosedur self healing. (Syifa Al-Qulub : Jurnal Studi Psikoterapi Sufistik. 2020). h.19.

${ }^{13}$ Siddik, I. N., \& Uyun, Q. Khusnudzon dan psychological well being pada orang dengan hiv/aids. h. 88 .
}

Al Qalam: Jurnal Ilmiah Keagamaan dan Kemasyarakatan Vol. 15, No. 2 Juli-Desember 2021 
Hardiyanti Rahmah : Konsep Berpikir Positif (Husnuzhon) Dalam Meningkatkan Kemampuan Self Healing

mereka alami nantinya, sehingga perilaku positif akan muncul sebagai respon dari pikiran positif seperti rasa percaya diri dan sikap yang lebih optimis.

\section{KESIMPULAN}

Berdasarkan hasil studi literatur yang sudah dilakukan, maka dapat disimpulkan bahwa kemampuan seseorang dalam melatih dirinya untuk berpikir positif (husnuzhon) dapat membantu dalam meningkatkan kemampuan pada proses self healing dari penyakit fisik dan permasalahan psikologis. Orang-orang yang mampu menerapkan konsep husnuzhon akan lebih mampu menjalani hidup dengan lebih baik karena berkurangnya rasa takut dan khawatir, serta meningkatnya kepercayaan diri dan sikap optimis yang membuat mereka mampu menjalani kehidupan dengan lebih sejahtera.

Al Qalam: Jurnal Ilmiah Keagamaan dan Kemasyarakatan Vol. 15, No. 2 Juli-Desember 2021 


\section{Daftar Pustaka}

Cita, E. E., Wulandari, T., \& Istanti, Y. P. Terapi islamic self healing terhadap quality of life pada klien gagal ginjal kronis dengan terapi hemodialisa. Muhammadiyah Jurnal of Nursing, 3(1), 43-57. 2016.

Dominggo, J. A., Parjo \& Herman. Pengaruh terapi self healing metode doa terhadap skor kecemasan pada lansia di panti jompo graha kasih bapa kecamatan sungai raya kabupaten kubu raya. Jurnal Proners, 4(1), 1-11. 2019.

Fairuzzahra, D. A., Aryandari, D,. \& Purwadi, M. Hubungan antara husnudzon dan kecemasan pada mahasiswa. Jurnal Psikologi Islam, 5(2), 69-74. 2018.

Holdcroft, B. What is religiosity? Journal of Inquiry and Practice, 10(1), 89-103. 2006.

Islami, L. A. Self Healing dalam mengatasi Post Power Syndrome. Skripsi. IAIN Sultan Maulana Hasanuddin Banten: Bimbingan dan Konseling Islam. 2016.

Moleong, L. J. Metodologi Penelitian Kualitatif. ROSDA : Bandung. 2014.

Salisah. Komunikasi spiritual sebagai kajian interdisipliner antara aspek keagamaan, ilmu kesehatan dan sains: studi tentang self-healing. Proceedings AICIS XII, 1115-1134. 2012.

Siddik, I. N., \& Uyun, Q. Khusnudzon dan psychological well being pada orang dengan hiv/aids. Psikis-Jurnal Psikologi Islami, 3(2), 86-93. 2017.

Rahmawati, A. P., Setiawan, C. \& Naan. Nilai sufistik dalam prosedur self healing. Syifa Al-Qulub : Jurnal Studi Psikoterapi Sufistik. 18-28. 2020.

Rusydi, A. Husn al-zhann: konsep berpikir positif dalam perspektif psikologi islam dan manfaatnya bagi kesehatan mental. Proyeksi, 7(1), 1-31. 2012. 